\title{
ON THE ABSORPTION OF WATER BY THE AËRIAL ORGANS OF SOME SUCCULENTS.
}

\author{
By S. SchönLAND, Ph.D., F.R.S.S.Af.
}

(Read June 16, 1909.)

Ever since the absorption of water by plants has been the subject of experimental inquiry, it has been known that water in liquid form can be absorbed by the leafy shoots of many plants, and that even the loss by transpiration of other parts of the same plant, which are not wetted, can be made good in this manner.* However, the shape and arrangement of leaves on the axis is frequently such as to prevent or hinder the formation of dew upon them. $\dagger$ Rain is usually easily drained off, and can, as a rule, not readily lodge on them. The absorption of liquid water by aërial parts of plants under artificial conditions is, therefore, in the majority of plants, only of academical interest. On the other hand there are cases, e.g., the epiphytic Bromeliacee, in which the plants are either without roots or provided with an imperfect root-system, and in which, therefore, absorption of water by aërial parts becomes a necessity. To a limited extent the utilisation of rain-water and dew may also occur in other plants, e.g., in cases where the leaf-sheaths collect a considerable amount of water. There remain a number of other cases in which water is supposed to be absorbed by means of special hairs or glands or by means of saline excretions of the leaves. Marloth $\ddagger$ has shown pretty conclusively that the saline excretions cannot serve to conduct water from rain or dew to the organs which secrete them. In his recently published

* See L. Kny, “Uber die Anpassung von Pflanzen gemässigter Klimate an die Aufnahme tropfbarflüssigen Wassers durch oberirdische Organe," Ber. d. d. bot. Gesellschaft, iv. (1886), p. xxxvi (where the literature up to that time is pretty fully quoted), and "Ueber die Aufnahme tropfbar-flüssigen Wassers durch winterlich-entlaubte Zweige von Holzgewächsen," Ibid. xiii. (1895), p. 361.

† Stahl, "Annales Jard. Buitenzorg," ii. (1893), p. 98, as quoted by Jost, "Lectures on Plant-Physiology," Engl. Ed. (1907), p. 32.

† R. Marloth, "Zur Bedentung der Salz abscheidenden Drüsen der Tamariscineen," Ber. d. d. bot. Gesellschaft, v. (1887), p. 319. 
work on the Cape Flora* he gives, however, some prominence to the absorption of water by special trichomes of certain succulents. Some cursory experiments, which I have conducted from time to time, do not bear out his views in this matter. $\dagger$ That many succulents may take up water through their aërial organs under special conditions arranged for them need not surprise us, for we have the old experiment by Wiesner that Sedum Fabaria can do so, but there is always to be remembered that such experiments have very little interest, unless they show us that the plant under natural conditions can replace more or less by its aërial organs the amount of water lost by transpiration. The experiments which I am going to describe were conducted to throw some fresh light on this question. While they cannot be regarded as the last word, even with reference to the limited number of plants experimented with, the answer they give is sufficiently plain to merit consideration.

I experimented with cut branches taken in each species from the same plants. These have the advantage that, when selected with reasonable care, they are in the same condition as regards water-contents. The cut stem can easily be sealed and the whole branches can easily be weighed on an ordinary chemical balance. They were taken from pot-plants which had been regularly watered when required. Except in cases which will be specially mentioned the cut end of each branch was at once carefully sealed with plasticine, to which a small quantity of vaseline had been added. Some of the branches were exposed on a table in the Botanical Laboratory of the Rhodes University College where the sun shone on them for several hours every day, others were exposed in the open, where the sun shone on them also for several hours, and where dew could be deposited on them. The position in the open was somewhat sheltered from strong westerly winds, which blew on several days. Temperaturereadings were taken occasionally, but as these could not be taken with sufficient regularity day and night, they are here omitted. It may suffice to state that the laboratory temperature ranged from $14-19^{\circ} \mathrm{C}$. in daytime. From the 15th to the 23rd of May the weather was rather warm for the time of year, while it was much cooler during the following week and warm again the third week. Altogether transpiration was necessarily much smaller than in the height of summer, while absorption of water, if taking place at all, would probably not be greatly affected by differences in temperature. There was a heavy dew every night, but only a slight rain fell in one night for a couple of hours, while branches were exposed in the open.

* R. Marloth, "Das Kapland, insonderheit das Reich der Kapflora, das Waldgebiet und die Karroo, pflanzengeographisch dargestellt," June, 1908.

† S. Schönland, "Morphological and biological observations on the genus Anacampseros, L.” Report S.A.A.A.S., 1903, p. 298. 
The fact that the cut ends of the branches were in most cases sealed with plasticine introduces a slight inaccuracy into the percentage of losses and gains, but they are not serious enough to vitiate the general conclusions which we can draw from them.

\section{Mesembrianthemum barbatum, L.}

Two branches, each with eight leaves.

I.

Kept in laboratory, a drop of water placed daily on the stellate hairs.

16/5/09 Weight, · $391 \mathrm{gr}$.

23/5/09 Weight, ·282 gr.

Loss in weight, $\cdot 109 \mathrm{gr} .=27 \cdot 9$ per cent

From May 23rd kept in the open, immersed daily for 15 minutes in water.

29/5/09 Weight, $\cdot 242$ gr.

Kept dry in laboratory.

Further loss, $\cdot 040$ gr. $=10 \cdot 2$ per cent. of original weight.

Total loss, $38 \cdot 1$ per cent.

16/5/09 Weight, $\cdot 498 \mathrm{gr}$.

23/5/09 Weight, $\cdot 390$ gr.

II.

Kept further in the laboratory, but immersed daily in water for 15 minutes, except on the last day when immersion lasted 5 hours.

29/5/09 Weight, $\cdot 361 \mathrm{gr}$.

Further loss, $\cdot 039$ gr. $=7.9$ per cent. of original weight.

Total loss, 30 per cent.

It is strange that in the specimen in which the hairs were moistened daily, the loss of water was greater than in the one which was kept dry. The same curious result was obtained with Anacampseros filamentosa. Whether this is only a coincidence has to be decided by further experiment. In any case it seems clear that the plant cannot make use of water placed on the stellate hairs, nor does exposure to dew and immersion to the extent to which the plant was subjected make good the loss of water by transpiration.

Anacampseros filamentosa, Sims.

Two branches.

I.

Kept in laboratory, hairs moistened daily.

16/5/09 Weight, $6 \cdot 211 \mathrm{gr}$.

23/5/09 Weight, 5·602 gr.

Loss, $\cdot 609$ gr. $=9 \cdot 8$ per cent. 
From 23/5,09 kept in the open, but immersed daily for 15 minutes in water. 29/5/09 Weight, 5•071 gr.

Further loss, $\cdot 531=8 \cdot 5$ per cent. of original weight.

Total loss, $18 \cdot 3$ per cent.

II.

Kept dry in laboratory.

16/5/09 Weight, $9 \cdot 277 \mathrm{gr}$.

23/5/09 Weight, 8.672 gr.

Loss, $\cdot 605$ gr. $=6 \cdot 5$ per cent.

Kept further in the laboratory, but immersed daily in water for 15 minutes, except on the last day when immersion lasted 5 hours.

29/5/09 Weight, 9.011 gr.

Gain, 339 gr., ${ }^{*}$ which still leaves a loss of $266 \mathrm{gr} .=2.9$ per cent. as compared with the original weight.

\section{Crassula cymosa, L.}

Four branches.

Exposed in the open, but otherwise not interfered with.

23/5/09 Weight, 5.62 gr.

29/5/09 Weight, 5·202 gr.

Loss, $\cdot 418$ gr. $=7 \cdot 5$ per cent.

II.

Exposed in the open, but immersed every

day in water for 15 minutes.

23/5/09 Weight, $7 \cdot 217$

29/5/09 Weight, 6·71.

Loss, $\cdot 507$ gr. $=7$ per cent.

III.

Kept in laboratory, but not interfered with.

23/5/09 Weight, 7·125 gr.

29/5/09 Weight, 6·29 gr.

Loss, $\cdot 835$ gr. $=11 \cdot 6$ per cent.

IV.

Kept in laboratory and immersed daily in water for 15 minutes, except on the last day when immersion lasted 5 hours.

23/5/09 Weight, 8.591 gr.

29/5/09 Weight, 7·864 gr.

Loss $\cdot 727$ gr. $=8 \cdot 5$ per cent.

Exposure to dew and immersion did not prevent considerable loss, though immersion conferred a slight advantage on branches subjected to it.

* This gain will be referred to again later on. 


\section{Experiments with Eosine Solution.}

On the 23/5 freshly cut branches of Mesembrianthemum barbatum and Anacampseros filamentosa were dipped in a strong, watery solution of eosine and left in the solution for twenty-four hours. In the first the stellate hairs were stained, everything else was unstained. This was confirmed by microscopic examination. In Anacampseros the long hairs were stained, everything else looked normal. Microscopical examination showed that no eosine had penetrated into stem or leaves. On the $24 / 5$ branches of all three kinds of plants experimented with were cut and left dry in the laboratory. The cut ends were not sealed in this case. All except Anacampseros showed external signs of withering on the 29/5; on that date their upper portions were dipped in eosine solution and left for twenty-four hours, after which they were examined. The result was as follows :-

Anacampseros: Hairs distinctly stained, otherwise no sign of red, either externally or internally.

Mesembrianthemum: Except stellate hairs, no part showed either externally or internally any signs of red.

Crassula: Papillæ faintly stained, vascular bundles in leaves and stem distinctly red, nothing else stained.

Thus this test only showed penetration of watery eosine solution in Crassula cymosa after the branches had been kept dry for nearly a week with the cut ends not sealed.

It seemed desirable, therefore, to determine in the first place whether the gain previously mentioned in Anacampseros after immersion in water for five hours was due to the fact that the water was sucked up by the hairs as by a sponge or whether the leaves themselves had absorbed it. The same two branches were therefore again weighed on the $30 / 5$, and it was found that while the one that had on the previous day been soaked for five hours had lost 8.3 per cent. of its weight the other, which had only been dipped for fifteen minutes, lost only 4.4 per cent. of its weight. They were then both immersed for twenty-five minutes in eosine solution and then weighed after having been dried as carefully as possible with blotting-paper. The former then showed actually a small gain on the previous day's weight; it weighed $9 \cdot 164$ gr., while the latter weighed 5.044 gr., which was a little less than the day before. However, no sign of red could be found in the interior of the plant, and this, in conjunction with the other facts mentioned, seems to show pretty conclusively that, as in Mesembrianthemum barbatum, no appreciable quantity of liquid water can enter the aërial organs from without. The gain in Anacampseros was evidently due to the absorption of water by the long, dead hairs and not by the leaves themselves. This gain is readily acquired, but also readily 
parted with. Such a wet sponge on the leaves will undoubtedly serve to retard transpiration, and in this connection the use of the hairs is obvious. There remains now only Crassula cymosa, into which eosine had penetrated in the experiment previously described.

Four branches of Crassula cymosa were cut on June 1st. Three had their cut ends sealed, one had not. Though still quite healthy, all showed decided signs of withering on June 6th. They were then immersed in strong, watery eosine solution for twenty-four hours, except their lower portions towards the cut ends. In none of them had the leaves regained their turgescence on the following day. After washing in water for five minutes the parts which had been immersed in eosine were found to be suffused with red, the marginal papillæ were, on the whole, only faintly stained, and in some of the younger leaves hardly stained at all ; the upper surfaces of the leaves were fairly evenly stained, in most leaves the under surface was also stained evenly, in others only the marginal portions, which, on the whole, showed more decided staining throughout. Microscopical examination of a strongly stained leaf showed the marginal papillæ very faintly stained, with contents practically colourless, the epidermis along the edge of the leaf with stained contents, other portions of the epidermis stained very little, the vascular bundles strongly stained. In the stem the contents of the epidermis cells and a few of the adjoining cells were slightly stained, the vascular bundles were strongly stained, and the eosine stain had also slightly diffused into the adjoining tissues; the bulk of the cortex, like the bulk of the mesophyll of the leaf, was unstained.

On the whole, the microscopic examination was decidedly in favour of the conclusion that the eosine solution penetrated through the marginal epidermal cells * and not through the papillæ. Thus these papillæ cannot be looked upon as water-absorbing organs unless they behave very differently in other species. Incidentally it was also shown that they cannot be looked upon as water-reservoirs, otherwise the eosine solution would certainly have penetrated into them more freely. However, as the solution which actually entered in twenty-four hours' immersion did not restore the turgidity of the mesophyll-cells it may safely be concluded that the power of taking up water possessed by the leaves (and evidently to a more limited extent by the stem) under experimental conditions is of absolutely no practical consequence to the plant under natural conditions.

This conclusion was strengthened by a further experiment with Crassula cymosa arranged after the manner of an old experiment figured by Pfeffer. $\dagger$ A large side-branch of a portion of a plant was immersed in

* Water-stomata, which are found in other species of Crassula, seem to be absent here. Most of the stomata all over the leaves were found open, the guard-cells as a rule slightly stained, but the eosine solution had, as a rule, not entered through the stomatal slit.

† W. Pfeffer, “The Physiology of Plants," Engl. Ed., vol. i. (1900), fig. 15, p. 160. 
water, while another side-branch, together with the stem bearing them, remained exposed to the air, the cut stem being carefully sealed. Within three days some of the leaves of the branch in air showed signs of becoming flaccid. These signs have increased daily, so that it is clear that the water lost by transpiration of the branch in air cannot be made good by the other branch immersed in water. The same result was obtained with Crassula multiflora, Schönl. et Bak. fil., which also possesses marginal papillæ on the leaves.

Summary.-Mesembrianthemum barbatum and Anacampseros filamentosa cannot absorb any appreciable quantity of water through their aërial organs. Crassula cymosa can do so to a small extent, which, however, cannot be of any practical importance under natural conditions. The marginal papillæ of this species are certainly not water-absorbing organs. The experiments throw doubts on the view that many other South African succulents can absorb by means of their aërial organs water of sufficient quantity to make good loss by transpiration. 


\section{$2 \mathrm{BHL}$ Biodiversity Heritage Library}

Schönland, S . 1910. "ON THE ABSORPTION OF WATER BY THE AËRIAL ORGANS OF SOME SUCCULENTS." Transactions of the Royal Society of South Africa 1, 395-401. https://doi.org/10.1080/00359191009520050.

View This Item Online: https://www.biodiversitylibrary.org/item/181696

DOI: https://doi.org/10.1080/00359191009520050

Permalink: https://www.biodiversitylibrary.org/partpdf/175471

\section{Holding Institution}

Smithsonian Libraries

\section{Sponsored by}

Biodiversity Heritage Library

\section{Copyright \& Reuse}

Copyright Status: Not in copyright. The BHL knows of no copyright restrictions on this item.

This document was created from content at the Biodiversity Heritage Library, the world's largest open access digital library for biodiversity literature and archives. Visit BHL at https://www.biodiversitylibrary.org. 